\title{
Degradation of Customary Inheritance Law in The Sai Batin Lampung Tribe
}

\author{
Yayan Sopyan ${ }^{1}$, Nusirwan², Isnawati Rais ${ }^{3}$, Asmawi $^{4}$
}

\begin{abstract}
Degradation of Customary Inheritance Law in The Sai Batin Lampung Tribe. The Sai Batin indigenous people use the "jujur" form of marriage the male majorate inheritance system, a system in which the oldest son is entitled to all inheritance and is the successor of their descendants. So strong is the position of sons in the family that if a family does not have a son, then the family is considered as having no or broken offspring. For this reason, in the Sai Batin kinship system, the adoption of a son, either from an internal or external family, is an alternative solution. This research is qualitative research using the Islamic Law Anthropology approach. In the data collection stage, the writer used the dept-interview technique combined with a survey. This research concludes that although most of the Sai Batin tribes still adhere to the customary inheritance system, however, there has been a tendency to no longer use customary law, especially in matters of inheritance, because it is considered unfair. This is indicated by the tendency of parents to bequeath property to all their children through a grant mechanism or to distribute inheritance based on Islamic inheritance law. This change is influenced by many factors, including the most dominant factors are education, economy, and social interaction.
\end{abstract}

Keywords: Jujur Marriage, Customary Inheritance Law, Degradation of Customary Law

\begin{abstract}
Abstrak: Degradasi Hukum Waris Adat di kalangan Suku Sai Batin Lampung. Masyarakat adat Sai Batin menggunakan bentuk perkawinan Jujur, dan menggunakan sistem kewarisan mayorat laki laki, yaitu sistem kewarisan dimana anak laki-laki tertua berhak atas seluruh harta peninggalan dan sebagai penerus keturunan mereka. Begitu kuatnya kedudukan anak lakilaki dalam keluarga sehingga jika suatu keluarga tidak memiliki anak laki-laki, maka keluarga itu dianggap tidak memiliki atau putus keturunan. Untuk itulah dalam sistem kekeluargaan Sai Batin, adopsi anak laki-laki, baik yang berasal dari lingkungan internal maupun ekternal keluarga, menjadi suatu solusi alternatif. Penelitian ini merupakan penelitian kualitatif yang menggunakan pendekatan Antropologi Hukum Islam. Dalam tahap pengumpulan data penulis menggunakan teknik dept-interview yang dikombinasikan dengan survey. Penelitian ini menyimpulkan bahwa meski sebagian besar suku Sai Batin masih berpegang teguh pada sistem kewarisan adat, namun, khususnya dalam masalah kewarisan, telah muncul kecenderungan untuk tidak lagi menggunakan hukum adat karena dipandang tidak adil. Hal ini ditunjukkan dengan kecenderungan para orang tua untuk mewariskan harta kepada seluruh anak-anaknya melalui mekanisme hibah, atau membagikan harta waris berdasarkan hukum waris Islam. Perubahan ini dipengaruhi oleh banyak faktor, diantaranya yang paling dominan adalah faktor pendidikan, ekonomi, dan interaksi sosial.
\end{abstract}

Kata Kunci: Perkawinan Jujur, Hukum Waris Adat, Degradasi Hukum Adat.

1,2,3,4 UIN Syarif Hidayatullah Jakarta, Jl. Ir H. Juanda No. 95, Ciputat, Tangerang Selatan

E-mail: 1yayan_sopyan@uinjkt.ac.id, ${ }^{2}$ nusirwang@gmail.com, ${ }^{3}$ Isnawati.rais@uinjkt.ac.id 


\section{Introduction}

Indonesia is a multicultural country that has a diverse population in terms of religion, language, culture, and customs. ${ }^{1}$ One of the various population groups is the Sai Batin indigenous people. The Sai Batin community is a Muslim community that adheres to customs. Dogmatically, they have strong customary laws that have been instilled by their ancestors through a book called Kuntara Raja Niti which is a written law and functions as a code of conduct. This book is used by almost every sub-tribe in Lampung, both the Pepadun Lampung community and the Sai Batin Lampung community. ${ }^{2}$

In marriage, the Sai Batin tribe uses the "Jujur" form of marriage, while in terms of inheritance they use the male "majorat" system of inheritance. "Jujur" marriage is a kind of marriage performed with payment from the male side to the female side. By receiving "Jujur" money or goods, it means that after marriage the woman will move her position from her own family to her husband's family for the rest of her life. A "Jujur" marriage is based on the lineage of the father so that each girl will think of herself as someone else's child. ${ }^{4}$ The Sai Batin inheritance system is almost the same as the inheritance system among the Rejang tribe. ${ }^{5}$ The main heir is the eldest son who gets and is entitled to all inheritance from his parents because he is seen as the successor of the offspring. ${ }^{6}$

Over time, the Sai Batin people slowly change their attitude in implementing the customary inheritance law. With various ways and reasons they begin to abandon their customary law because it is deemed

${ }^{1}$ Nurcholish Madjid, Islam Doktrin dan Peradaban (Jakarta: Yayasan Wakaf Paramadina, 1992); see alson Najib Burhani, Kebinekaan Kita (Daily Compass, 2020).

${ }^{2}$ Fachruddin, 'Memahami Etika dalam Kitab Kuntara Rajaniti Dalam Rangka Mengenal Identitas Budaya Lampung', <http://ulun.lampunggech.com/2008/10/manuskrip-kitab-kuntararaja-niti.html>.

${ }^{3}$ Hilman Hadikusuma, Hukum Perkawinan Adat, (Bandung: Citra Aditya Bakti, 1990), p. 73.

${ }^{4}$ Hilman Hadikusuma, Hukum Perkawinan Adat, p. 73.

${ }^{5}$ Aji Abdullah Siddik, Hukum Adat Rejang (Jakarta: PN Balai Pustaka, 1980).

${ }^{6}$ Hilman Hadikusuma, Masyarakat Dan Adat Budaya Lampung (Bandung: Mandar Maju, 1989), p. 119. 
not fulfilling a sense of justice. This change in trend is, of course, interesting and important to study.

As far as the authors have traced, the discussion of the degradation of customary law in the field of inheritance law, especially among the Sai Batin indigenous people, is still rare. The following shows previous studies relating to the customary law of Sai Batin and the degradation of customary law. (1) Ali Imron, and Rinaldo Adi Pratama, Perubahan Pola-pola Perkawinan pada Masyarakat Lampung Saibatin, Journal of Anthropology: ${ }^{7}$ This article explains that since the 1970s the marriage pattern of the Saibatin tribe has undergone a change from the very strong "Bujujogh" marriage system with the patrilineal to the Semanda system. The people of Lampung Saibatin developed a new marriage system using Semanda because of the influence of the Minangkabau people as they were reluctant to be called a failed family or "mupus". (2) Meli Septania Adelina Hasyim Hermi Yanzi, Implementasi Nilai Kearifan Lokal dalam Proses Upacara Pernikahan Adat Lampung Saibatin ${ }^{8}$. The study finds out that there has been a shift in carrying out the traditional ceremony of marriage in the form of simplifying the ceremony and not using traditional ceremony in full because of the expense, taking long time and energy, as well as not knowing the complete sequence of traditional processions. (3) Atiansya Febra, Rachmat Budiono and Chusen Bisri, Sistem Perwarisan Masyarakat Adat Saibatin Dalam Keluarga yang Tidak Mempunyai Anak Laki-laki (Studies in Bandar Lampung)', This study finds out that, in special circumstances, a family not having a son is possible to adopt a child through a traditional marriage of semanda (ngakuk ragah) so as not

7 'Perubahan Pola-Pola Perkawinan Pada Masyarakat Lampung Saibatin | Imron | Jurnal Antropologi: Isu-Isu Sosial Budaya' <http://jurnalantropologi.fisip.unand.ac.id/ index.php/jantro/ article/view/216> .

${ }^{8}$ Meli Septania Adelina Hasyim Hermi Yanzi, 'Implementasi Nilai Kearifan Lokal dalam Proses Upacara Pernikahan Adat Lampung Saibatin', Journal of Democracy Culture (JKD), 5.5, 2017.

${ }^{9}$ Atiansya Febra, 'Sistem Perwarisan Masyarakat Adat Saibatin dalam Keluarga Yang Tidak Mempunyai Anak Laki-Laki (Studi di Kota Bandar Lampung)', Kumpulan Jurnal Mahasiswa Fakultas Hukum, 0.0 (2015) <http://hukum.studentjournal.ub.ac.id/ index.php/hukum/article/ view/1364>. 
to break off the offspring. The son from that marriage will then be entitled to the inheritance. In terms of dispute resolution, the Saibatin customary people of Bandar Lampung use the deliberation method and traditional deliberation family.

From the articles above, perhaps Atiansya's writing is closer to the object of this study, only Atiansya focuses more specifically on the inheritance of the Saibatin tribe, which has no male descendants, while this article is highlighting the phenomenon of the degradation of the laws of inheritance to the Sai Batin tribe. Regarding the issue of the shift in the cultural value of Sai Batin, such has been elaborated by Prima Angkupi, ${ }^{10}$ Formulasi Perkawinan Adat Lampung Dalam Bentuk Peraturan Daerah dan Relevansinya Terhadap Hak Asasi Manusia. This article discusses local regulation No. 2/2008 which regulates the issue of Lampung Cultural Maintenance. The purpose of this local regulation is as a legal standing for recognition of customs and a means to fight for the attainment of cultural values. But in reality, it is contrary to the spirit of exploring the values that live in the society itself. Article 16 paragraph (1) of local Regulation No. 2 the year 2008 concerning the Maintenance of Lampung Culture states that Customs and Culture of Lampung related to a traditional marriage must be maintained and developed. However, there is a practice that needs to be criticized, namely eloping. According to this study, eloping is no longer relevant to the current social conditions of the Lampung people because there has been a change in the meaning of eloping which has turned into a violation of the law and women's constitutional rights. The eloping that fails to heed the consent of the girl side is contrary to human rights and national marriage laws. Therefore, the formulation of Article 16 of the local regulation on the maintenance of Lampung culture in the form of eloping is unconstitutional and contrary to the spirit of human rights.

${ }^{10}$ Prima Angkupi, 'Formulasi Perkawinan Adat Lampung dalam Bentuk Peraturan Daerah dan Relevansinya Terhadap Hak Asasi Manusia', Asy-Syir'ah: Jurnal Ilmu Syariah dan Hukum, 49.2 (2015), 315-37 <https://doi.org/10.14421/asy-syir'ah.2015.\%x>. 


\section{Inheritance Law and Legal Shift: a Theoretical Review}

Three systems of inheritance law apply in Indonesia, namely the customary inheritance law, Islamic inheritance law, and the Western inheritance law that is regulated in Civil Law. ${ }^{11}$

Customary inheritance law has various patterns, depending on the kinship structure adopted. Different kinship systems will give rise to different laws. ${ }^{12}$ The kinship system in Indonesia consists of three, namely the patrilineal system which follows the father's lineage, the matrilineal system which follows the maternal line.

The system of kinship that exists in Indonesia consists of three, namely the patrilineal system that follows the father's lineage, the matrilineal system that follows the mother's lineage, and the bilateral system which follows the father's and mother's lineage. ${ }^{13}$

The major system is divided into two, the male mayor is adopted by the Sai Batin people in Lampung, and the female mayor is adhered to by the Semando indigenous people in South Sumatra.

In the distribution of inheritance, there are 3 systems adopted. ${ }^{14}$ First, the individual inheritance system, where each heir receives a share of the inheritance to be controlled or owned in accordance with their respective share. The second is the collective inheritance system, where inheritance is passed on and transferred from the heir to the heirs as a unit but the owner cannot be distributed, quite similar to the Pusako Tinggi in Minangkabau where the control, management, and utilization are left under family deliberation. ${ }^{15}$ The third is the majorate inheritance system, where the transfer of rights to the property is not divided but is delegated to the eldest son who serves as the leader in the family and who replaces the father's position as head of the household. The majorate

${ }^{11}$ Komari, 'Laporan Akhir Kompendium Bidang Hukum Waris' (Jakarta: Agency for Development of National Law, the Ministry of Justice and Human Right, 2011).

${ }^{12}$ Sigit Sapto Nugroho, Hukum Waris Adat Di Indonesia (Solo: Pustaka Iltizam, 2016).

${ }^{13}$ Sigit Sapto Nugroho, Hukum Waris Adat Di Indonesia.

${ }^{14}$ Sigit Sapto Nugroho, Hukum Waris Adat Di Indonesia, p. 7.

${ }^{15}$ Yaswirman, Hukum Keluarga: Karakteristik dan Prospek Doktrin Islam dan Adat Dalam Masyarakat Matrilineal Minangkabau (Depok: Raja Grafindo Persada, 2017), pp. 147-66. 
system is divided into two, the male majorate system adhered to by the Sai Batin people in Lampung, and the female majorate adhered to by the Semendo customary people in the South of Sumatra. ${ }^{16}$

As Ibn Qayyim al-Jauziyah stated in his book, the law is greatly influenced by changes in time, place, local situation, and conditions. ${ }^{17}$ This theory cannot be refuted due to the fact that socio-cultural changes occur at any time, in line with the development, progress, and changes in the society itself. In responding to these changes some people can accept it completely, some accept it half-heartedly and some even reject it. Every society has a style and way of accepting the cultural changes as a form of a shift in the views and socio-cultural values of the society that evolutionarily take place. ${ }^{18}$

In Islam, the rules that are based on the Qur'an, Sunnah, and ijma ulama, including Islamic inheritance law, are considered permanent and not open to changes all the time. Not all Muslims, however, cling to the dogma firmly. One of them is Munawwir Sadzali, who argues that the law of inheritance can be changed according to the situation and condition of society. ${ }^{19} \mathrm{He}$ also explains that Islamic inheritance law in Indonesia is experiencing degradation. Such a view, initially, sparks a harsh reaction, especially from the Muslim scholar. ${ }^{20}$ However, as time passes, the view begins to receive the spotlight from Indonesian Muslims, as later appear in the Islamic Indonesian inheritance law. ${ }^{21}$

The same is true in the customary law of Indonesia, even more, significant as the law Institutions become less authoritative and even

${ }^{16}$ Hilman Hadikusuma, Masyarakat dan Adat Budaya Lampung, p. 36. t.t), p. 3 .

${ }^{17}$ Ibn Qoyyim al-jauziyah, I'lamul Muwaqiin, III (Beirut: Dar al- Kutub al-Arabiyah,

${ }^{18}$ Koesno Wardojo, 'Pergeseran Pandangan Terhadap Nilai Sosial Budaya Dalam Masyarakat Sebagai Akibat Pengaruh Kebudayaan', Equilibrium : Jurnal Ilmiah Ekonomi Dan Pembelajarannya, 1.1 (2013) <https://doi.org/10.25273/equilibrium.v1i1.553>.

${ }_{19}$ Munawir Sjadzali, , Ijtihad Kemanusiaan (Jakarta: Paramadina, 1997), pp. 61-62.

${ }^{20}$ Satria Effendi M Zein, 'Munawir Sjadzali Dan Reaktualisasi Hukum Islam Di Indonesia', in Kontekstualisasi Ajaran Islam, 70 Years Prof. Dr. Munawir Sjadzali, MA (Jakarta: Paramadina, 1995), p. 292.

21 'Hukum Waris dan Wasiat (Sebuah Perbandingan Antara Pemikiran Hazairin Dan Munawwir Sjadzali) | Jamil | Al-Ahwal: Jurnal Hukum Keluarga Islam', p. $100<$ http://ejournal. uin-suka.ac.id/syariah/Ahwal/article/view/1171>. 
almost extinct. ${ }^{22}$ In some places, customary law is slowly being eroded by the times and some are dying and some even have died. ${ }^{23}$ The factors that influence the degradation of customary law are both internal and external. One of the external factors is the choice of the Indonesian legal system which chooses civil law and common law systems and leads to the codification and unification of law. In addition to the changes in the obedience of society to the law, there are also changes in the values, attitudes, and behavior of the community. ${ }^{24}$ This external dynamics of the law is seen as something that inevitably occurs due to natural factors that many parties worry about. ${ }^{25}$

Legal degradation can be described as a decrease in the use of law and a shift to another legal system that is seen as better and fairer. This is due to parallels situation that provides an alternative for customary communities to exercise their choice of law to regulates their interests. ${ }^{26}$

Inheritance law based on customary law is a consequence of the existence of an autonomous society that regulates legal relations. In the customary communities, certain social groups create a mechanism for regulating inheritance law with recognized legal norms and institutions. At the same time, however, the law is mixed with other laws that are also recognized its existence. The existence of society, along with the agreed norms, therefore, becomes semi-autonomous because it is influenced by external factors that cause the diversity of laws in various aspects of

${ }^{22}$ Rahman et al, 'Kajian Hukum Tentang Mekanisme Pengakuan Masyarakat Adat' (Center for Research and Development Systems National Law and Development of the National Law Kemenkumham RI, 2015), p. 30.

${ }^{23}$ Teguh Kayen, 'Hukum Adat Dihadapan Politik Hukum Nergara: Studi Sosiologis Hukum Masyarakat Adat Rejang', Jurnal Jurisprudence, 5.2 (2017), 75-79-79 <https://doi.org/10.23917/ jurisprudence.v5i2.4223>.

${ }^{24}$ Achmad Sodiki, 'Penataan Kepemilikan Hak Atas Tanah Di Daerah Perkebunan Kabupaten Malang. (Studi Tentang Dinamika Hukum).' (Airlangga University Postgraduate Program, 1994), p. 43.

${ }^{25}$ Adil Niat Gulo, 'Degradasi Budaya Dalam Upacara Perkawinan Masyarakat Nias Di Denpasar, E-Jurnal Kajian Budaya (Online Journal of Cultural Studies)' <https://ojs.unud.ac.id/ index.php/kajian/article/view/4826>.

${ }^{26}$ Husen Alting, 'Penguasaan Tanah Masyarakat Hukum Adat (Suatu Kajian Terhadap Masyarakat Hukum Adat Ternate)', Jurnal Dinamika Hukum, 11.1 (2011), 87-98 (p. 96) $<$ https://doi.org/10.20884/1.jdh.2011.11.1.75>. 
life. ${ }^{27}$ This condition is what Selly Falk Moore calls the Semi-Autonomous Social Field. ${ }^{28}$

Arnold M. Rose argues that legal change is influenced by three factors, namely progressive communication which is the impact of technological discovery, the existence of contact or conflict in people's lives, and social movements. ${ }^{29}$ Legal change occurs when two elements meet at one point of contact, that is (1) the emergence of new circumstances and (2) awareness of the need for change in the society concerned itself. ${ }^{30}$ According to Ridwan the factors that encourage legal change in a society include contact with other cultures, an advanced education system, tolerance for deviant behavior, open stratification, heterogeneous populations, and dissatisfaction with certain areas of life. ${ }^{31}$ External factors that are no less important as the cause of change are globalization. Globalization in the form of trade, communication, and development patterns is one of the driving factors for legal change. In such a situation, values and a series of influences that are inherent globally cannot be isolated or even avoided, so it is not uncommon to arise for resistance over global values. ${ }^{32}$

\section{The Sai Batin Tribe}

The indigenous peoples of Lampung are historically and culturally divided into two large tribal communities, namely the Pepadun and the Sai Batin (Pesisir). ${ }^{33}$ The Pepadun comes from a traditional tool used in the

${ }^{27}$ Ibid, p. 97.

${ }^{28}$ Sally Falk Moore, 'Law and Social Change: The Semi-Autonomous Social Field as an Appropriate Subject of Study', Law \& Society Review, 7.4 (1973), 719-46 <https://doi. org/10.2307/3052967>.

${ }^{29}$ Pokok-Pokok Sosiologi Hukum Pokok-Pokok Sosiologi Hukum (Jakarta: Rajawali Pers, 2011), p. 110.

${ }^{30}$ Ridwan Ridwan, 'Hukum dan Perubahan Sosial:(Perdebatan Dua Kutub Antara Hukum Sebagai Social Control dan Hukum Sebagai Social Enginnering)', Jurnal Jurisprudence, 6.1 (2017), 28-39-39 (p. 31) <https://doi.org/10.23917/jurisprudence.v6i1.2993>.

${ }^{31}$ Ibid.

${ }^{32}$ Hari Purwadi, 'Reformasi Hukum Nasional: Problem Dan Prospeknya', in Memahami Hukum: Dari Konstruksi Sampai Implementasi (Jakarta: Rajawali Press, 2011), pp. 64-65.

${ }^{33}$ Syarifudin Basyar, Determinasi Nilai-Nilai Tradisi Terhadap Religiusitas Masyarakat (Kajian Adat Ninjuk Dalam Budaya Lampung (Lampung: Research and Publishing Center, LPPM IAIN Raden Intan Lampung, 2014), p. 6. 
Cakak Pepadun procession which means a wooden bench or throne, a symbol of certain social status in the family. ${ }^{34}$ The Pepadun tradition tends to be democratic $^{35}$ as it is possible to change one's social status through certain traditional ceremonies. ${ }^{36}$ The Sai Batin or Saibatin, on the other hand, means one mind or one ruler because in the tribe there is only one customary king in each generation of leadership. The Sai Batin culture tends to be aristocratic because customary positions can only be inherited through bloodlines. ${ }^{37}$

The two tribes, in principle, are consistent, steadfast, and obedient in upholding the traditional values and cultural heritage of their ancestors. The philosophy of life of Ulun Lampung (the people of Lampung) is known as Piil Pesenggiri (self-respect or shame to do disgraceful acts). The philosophy of Piil Pesenggiri consists of four noble values, namely: (1) "Nemui Nyimah", the principle of openness and giving to one another in life. (2) "Bejuluk Beadok", mutual respect and tolerance. (3)"Nengah Nyappukb", participation and mingling in society, and (4) "Sakai Sambaian", mutual help. ${ }^{38}$

Genealogically, the people of Lampung are people who adhere to the Patrilineal family system. Lampung people groups according to the descent by "Poyang (great-great-grandfather)" origin of each is called to "buway". Each buway consists of several Jurai, from buway which is also divided into several relatives who are tied to one unit of the house of origin (nuwou tuhou). Then the house of origin was divided again into several relatives' houses (nowou sanak). There are times when buway-s were joined in a unity which is called Paksi. ${ }^{39}$

The majority of Pepadun people live in central area of Lampung such as: Abung, Way Kanan, Sungkai, Tulang Bawang and Gunung Sugih areas.

34 'Masyarakat Adat Lampung Saibatin : Tradisi - Situs Budaya Indonesia' <https: //www. indonesiakaya.com/jelajah-indonesia/detail/masyarakatadat-lampungsaibatin $>$.

${ }^{35}$ Edward Syah Pernong, '100 Tokoh Terkemuka Lampung', Lampung Post, 2008, p. 325.

${ }^{36}$ Muhammad Aqil Irham, 'Lembaga Perwatin Dan Kepunyimbangan Dalam Masyarakat Adat Lampung: Analisis Antropologis', Analisis: Jurnal Studi Keislaman, 13.1 (2013), 155-72 (p. 157) <https://doi.org/10.24042/ajsk.v13i1.684>.

37 'Masyarakat Adat Lampung Saibatin : Tradisi - Situs Budaya Indonesia', Ibid.

${ }^{38}$ Hilman Hadikusuma, Masyarakat dan Adat Budaya Lampung, pp. 158-59.

${ }^{39}$ Ibid. 
In terms of kinship, Pepadun has four major clans, namely: (1) Abung Siwo Migou (Abung nine clans) (2) Tulang Bawang Megow Pak (Tulang Bawang four clans) (3) Way Kanan Buwai Lima (Way Kanan five clans) (4) Pubiyan Telu Suku (Pubiyan three clans). On the other hand, The Sai Batin live on the coastal areas of Lampung and have several clans, namely (1) the Sekampung Ilir Melinting clan who inhabits the Way Sekampung Ilir area. (2) The Rajabasa Melinting Coastal Clan who inhabits the foot of Mount Rajabasa and its surroundings. (3) The Teluk Pesisir clan who inhabits the vicinity of Lampung Bay. (4) The mainland clan of Semangka on the Teluk Semangka Beach. (5) The Krui-Belalau Coastal Clan is an ex-Kewadanaan Krui (6) the Danau Ranau clan who inhabits the Komering area up to the Kayu Agung, South Sumatra Province. ${ }^{40}$

Besides, the people of Lampung have the philosophy of Sang Bumi Ruwa Jurai, which means a household of two lineages, giving birth to the Pepadun and the Sai Batin people. The people of the Lampung tribes, both the Pepadun and the Sai Batin, admit that their descendants come from Sekala Brak, the mountainous area of Belalau Bukit Barisan. ${ }^{41}$

\section{The Book of Kuntara Raja Niti, the Law of Sai Batin Customary People}

Fachruddin explained that there are two versions of the Kuntara Raja Niti book circulated in the community. ${ }^{42}$ One version is written in the Lampung script and another version is written in the Pegon script, an Arabic script originating from Banten. ${ }^{43}$ The Kuntara Raja Niti book was heavily influenced by animism, Hinduism, and Islam. The book consists of two parts, the first part is written in the 17th-century style of Lampung script, using sleeping letters as compared to the contemporary Lampung script; another part is written in Arabic script without a phonetic sign

\section{${ }^{40}$ Ibid.}

${ }^{41}$ Ibid.

${ }^{42}$ It is an alarming condition that the young generation of Lampung Lampun now tend to be indiffferent and reluctant to learn the Lampung script as they consider it no longer important and out of date. For further read Titik Pudjiastuti, Aksara Dan Naskah Kuno Lampung Dalam Pandangan Masyarakat Lampung Kini, (Jakarta: Putra Sejati Raya, 1996), p. 78.

${ }^{43}$ Fachruddin, 'Memahami Etika Dalam Kitab Kuntara Rajaniti Dalam Rangka Mengenal Identitas Budaya Lampung',. 
(syakl) and uses the Central Javanese language with a Banten accent. ${ }^{44}$ Each section contains the entire contents of the Kuntara Raja Niti book, in the sense that one part is transcribed in another. ${ }^{45}$

Customarily, the book is passed down from earlier to the next generation and stored in the house of the customary leader (Punyimbang) at each cradle. Unfortunately, although the Punyimbang is custodians of heirlooms, both material and objects, not all of them have the manuscript. Therefore, for clans who do not own the Kuntara Raja Niti book, the delivery of the book has to be given orally.

The contents of the Kuntara Raja Niti are not just a matter of customary procedures in a purely ceremonial sense, but also public order or statutory regulations. ${ }^{46}$ As stated in the manuscript, the Kuntara Raja Niti and Jagul Muda Books are the Law Books that apply in three regions, namely: Majapahit, Padjadjaran, and Lampung. ${ }^{47}$ As a law book regulating social law, this book was written systematically.

The first chapter of the book Kuntara Raja Niti discusses "qiyas (analogy) "which involves three things, namely: (1) Kuntara (2) Raja Niti (3) Jugul Muda. The second chapter describes the three kings who have policies, namely King Prabu Sasmata from the Majapahit Kingdom, King Pakuan Sandikara from the Padjadjaran Kingdom, and Raja Angklangkara from the Lampung Kingdom. This chapter also describes the majesty of the king of Majapahit. Chapter III explains the three main laws among the principles of law in the Kuntara Raja Niti book, namely: igama, dirgama, and karinah. Igama, the law, means something real and visible whose existence and truth can be recognized by all. Dirgama, conscience,

${ }^{44}$ The influence of the power Kingdom of Banten is quite real for Sai Batin Tribe, especially in the making of laws that set out in the Book of Kuntara Jara Niti, because in Banten itself much regulatory legislation that was written more in advance. More Further reading Ayang Utriza Yakin, 'Undhang-Undhang Bantěn', Indonesia and the Malay World, 44.130 (2016), 365-88 $<$ https://doi.org/10.1080/13639811.2016.1229859>.

${ }^{45}$ Fachruddin, 'Memahami Etika Dalam Kitab Kuntara Rajaniti Dalam Rangka Mengenal Identitas Budaya Lampung',.

${ }^{46}$ Ninawati Syajrul, 'Upaya Dan Penyelamatan Naskah Kuno Lampung | Manuskripta', Journal, Manuscriptta, 1.2 (2011) <http://journal.perpusnas.go.id/index.php/manuskripta/article/view/14>.

${ }^{47}$ Bunyana Sholihin, 'Hukum Bangsa Indonesia Dalam Naskah Klasik Beraksara Lampung (Undang-Undang Kuntara Rajaniti Dan Jugulmuda)', ASAS, 11.01 (2019), 38-48<https://doi. org/10.24042/asas.v11i01.4641>. 
law according to conscience. Meanwhile, Karinah is related to the legal actions that have been taken. With these three basic provisions, the law can be classified as The real law, namely Kuntara, the law that follows the conscience, that is called Raja Niti, while the law relating to the cause and effect of an action, that is called Jugul Muda. Furthermore, Chapters IV, V, and VI discuss the problem of rules in Chapter III. The details of legal products or statutory regulations can be found in chapters VIII to chapter XVII. Chapter VIII describes the law on husband and wife matters. Chapter IX discusses the issue of buying and selling, Chapter X discusses land. Chapter XI discusses debt and credit, Chapter XII discusses Pawn and Wages. Chapter XIII discusses the ethics of visiting and staying overnight. Chapter XIV on prohibitions. Chapter XV deals with covenants. Chapter XVI discusses matters of divorce, while chapter XVII discusses debt and credit. Environmental and ethical issues are also included in the discussions, for example, the problem of boating and using water, ethical issues of visiting, such as a visit by a man to a house inhabited by a woman while her husband is not there. Each chapter in the book contains not only regulations but also sanctions for violating these regulations. The Law Book was purely a creation of the Lampung people as it has existed before the Dutch coming and making a separate Law. ${ }^{48}$

\section{Marriage and Inheritance in the Sai Batin's Customs}

Marriage is an important event in people's life. Marriage is a legal union between a man and a woman for the whole life. ${ }^{49}$ The purpose of marriage is to form a happy and ever-lasting family. For this reason, husband and wife need to help and complement each other so that each can develop his personality, achieve personal well-being, and achieve spiritual and material well-being. ${ }^{50}$

For Indonesians who still uphold customary and cultural values, marriage is not only related to husband and wife but also involves parents

\footnotetext{
${ }^{48}$ Fachruddin, 'Memahami Etika Dalam Kitab Kuntara Rajaniti Dalam Rangka Mengenal Identitas Budaya Lampung'.

${ }^{49}$ R. Soebekti, Pokok-Pokok Dari Hukum Perdata, (Jakarta: Intermassa, 1985), p. 20.

${ }^{50}$ Sudarsono, Hukum Perkawinan Nasional, (Jakarta: Rineka Cipta, 1981), p. 9.
} 
from both parties, siblings, and ethnicity. Marriage customary law is an unwritten law that explains the provisions for marriage. Regarding the validity of a marriage, customary law depends on the kinship system adhered to by the legal community where the prospective bride and groom live.

Sai Batin's traditional marriages are based on Patrilineal marriages or following the paternal lineage. In the patrilineal kinship system, a woman, due to her marriage, becomes separated from her parents, ancestors, and siblings. In Sai Batin's law, it is called "jujur" marriage. According to Hilman Hadikusuma, the form of a "jujur" marriage is a marriage that is carried out with "jujur" payments from the side of the man to the woman. By accepting "jujur" in the form of money, goods, or property, a woman after marriage will transfer her position to her husband's relative's membership for good and bind herself to the husband's family. Both personal and property brought will be subject to the husband's customs unless there is another customary law relating to certain carry-on items. ${ }^{51}$

After the wife is in the hands of the husband, the wife with all her legal actions must be with the husband's approval or with the husband's relative's consent. A wife cannot act alone. She is an assistant of her husband in managing household life, both in kinship and in social relations. ${ }^{52}$ Among customary peoples, some adhere to a jujur marriage system and draw lineages based on their father, each girl will consider herself someone else's child. ${ }^{53}$

There are several variations of Jujur marriage. First, the change of husband in the case of the husband died. If a husband died, the wife must marry the brother of her deceased husband. In this marriage, there is no need for jujur payments anymore. ${ }^{54}$ Second, the change of wife in the case of the wife died. When the wife died, the husband remarries the deceased wife's sibling. The main purpose of this marriage is to provide a solution in case the dead wife does not have children as the substitute wife

${ }^{51}$ Hilman Hadikusuma, Hukum Perkawinan Adat, p. 73.

${ }^{52}$ Dewi Wulansari, Hukum Adat Indonesia Suatu Pengantar, 3 (Bandung: Refika Aditama, 2014), p. 52.

${ }^{33}$ Hilman Hadikusuma, Hukum Perkawinan Adat, p. 73.

${ }^{54}$ Dewi Wulansari, Hukum Adat Indonesia Suatu Pengantar, p. 53. 
can provide offspring for the family successor. Third, servant marriage. When the male side's application fails to meet the requirements set by the woman's family, whereas from both sides of the family do not want the marriage to be separated, then the husband, after the marriage, will not stay with his relatives but to be on the side of the wife's relative. ${ }^{55}$ In Sai Batin's tradition, there is no recognition of the separation of property between husband and wife, because when a marriage occurs, the marriage system determines the status of the property. If the marriage system is jujur, the wife carries assets, then the assets will be mixed with the husband's assets and are considered joint assets. ${ }^{56}$

Nowadays, jujur marriages are rare in the Sai Batin communities. ${ }^{57}$ The reasons are the high costs incurred, the length of the marriage process, as well as other factors that have been heavily influenced by Islamic law. To fulfill the requirement of a jujur marriage, which is quite expensive, the entire extended family helps to contribute in-kind and money. Such has become a habit from generation to generation. The background of the high amount of jujur money is because the money will be bought for household items such as cabinets, beds, chairs (Barang Batinok), etc. This means that the jujur money given by the male side is not used for other purposes but to buy things that will be carried by the women. Interestingly, the amount of jujur money can also function as a way to refuse an application, especially if a woman's parents do not agree with their daughter's choice. Therefore, the man may cancel his intention as he can not afford such a large of money. ${ }^{58}$ This strategy, however, may provoke a bad impact, causing the couples in love to seek a shortcut, that is to conduct eloping.

In terms of inheritance, the Sai Batin community adheres to a majorat system where the inheritance cannot be shared and only controlled by the eldest son. The eldest son in Sai Batin customs plays an important

\footnotetext{
${ }^{55}$ Dewi Wulansari, Hukum Adat Indonesia Suatu Pengantar, pp. 54-56.

${ }^{56}$ Batin Juragan Muhammad Rusli, 'Personal Interview'.

${ }^{57}$ Marwan, Pratin Bumi Agung, Personal Interview, 2018.

${ }^{58}$ M. Adnan Bahsan, Zulchilal Bahsan and Badri Bahsan, 'Pelestarian Nilai-Nilai Adat Dan UpacaraPerkawinan Adat Lampung Pesisir' (presented at the Paper presented at the Anniversary of the University of Lampung, Lampung, 1982), p. 35.
} 
role in his extended family. He is considered as a substitute for the head of the family so that he is obliged to take full responsibility in maintaining, serving, and protecting his family, both in terms of managing the inheritance left by his parent, as well as for family members. Although the eldest son controls the right to use, process, and collect crops, he, in turn, should look after his younger siblings until they can stand on their own. He is also burdened in maintaining sustainable balance and the good name of the family. When the eldest son dies, the rights and responsibility are passed down to the second son and so on, only the daughter cannot be the recipient of the inheritance. ${ }^{59}$

At first glance, both materially and morally, this kind of inheritance sharing system seems unfair. From an economic point of view, the eldest son will be greatly disadvantaged and the lucky ones are other siblings who cannot inherit. This is because the eldest son, despite his rights, is also burdened with many obligations, such as the responsibility to facilitates the expenses when his siblings marry, to attend marriage invitations, to be present in death events, to pay customs fees, to help to build a house, to planting rice, and so on, all are borne by the eldest son.

In Sai Batin's custom, there are two types of inheritance, the first inheritance cannot be shared or controlled individually but owned together by the heirs. These inheritance assets are called the inheritance of heirloom which is passed down from the inheritor to the successors of their descendants. This treasure is controlled by punyimbang, the head of family groups). These assets can be in the form of heirloom weapons, traditional clothes, yards, houses, buildings, agricultural land, plantations, as well as immaterial heirlooms, such as customary titles, customary positions, rights to traditional clothing, the right to organize and represent members of relatives. etc. ${ }^{60}$

Inheritance assets that can be shared in the Sai Batin people are assets that the parents produce while they are still alive, not inherited assets from their ancestors. For these assets, the distribution process is

\footnotetext{
${ }^{59}$ Hilman Hadikusuma, Masyarakat Dan Adat Budaya Lampung, p. 19.

${ }^{60}$ Batin Juragan Muhammad Rusli, Interview'.
} 
employing transmission or appointment. The distribution can be done during the heir is still alive or after he/she dies. In such a situation, both the sons and daughters have the same right to inherit from their parents. However, if the parent dies, and there are still assets that have not been distributed to the living children, then the property becomes the son's absolute right. ${ }^{61}$

\section{Degradation of Adherence to Customary Laws}

Lex iniusta not est lex, ${ }^{62}$ unjust laws are not true laws. Good law is the law that has authority because it is respected, obeyed, and followed by society. The law must serve as a tool for resolving conflicts that arise in society. When people deny, disobey or turn away from the law, it is necessary to question the nature of the law as a means of resolving conflicts. Therefore, according to Pospisil, the law must be assimilated into justice and that law without justice is a mockery. ${ }^{63} \mathrm{~A}$ law must be combined with justice to be a truly meaningful law because the purpose of the law is to create a sense of justice in society.

Currently, a shifting of law occurs in the Sai Batin tribe. The main factor affecting the shift in law among the Sai Batin tribe is motivated by a sense of justice that is felt to be no longer present in the customary inheritance law. The researcher found that there were not a few of the Sai Batin indigenous peoples who were involved in family conflicts due to the distribution of inheritance which they thought unfair. As a result of the distribution, the brotherly relationship between fellow biological children was disturbed or even broken. They no longer visited or greeted each other. This was acknowledged by several community leaders through their statements as follows:

${ }^{61}$ Batin Juragan Muhammad Rusli, Personal Interview, 2018.

${ }^{62}$ Sayings were spoken by Saint Augustine, later elaborated on by Aquinas et al. see Norman Kretzmann, 'Lex Iniusta Non Est Lex: Law on Trial in Aquinas' Court of Conscience', The American Journal of Jurisprudence, 33.1 (1988), 99-122 <https://doi.org/10.1093/ajj/33.1.99>; see also David Knowles, O.S.B.; D. Litt.; F.B.A., 'Lex Injusta Non Est Lex', The Catholic Lawyer, 2.3 (2016) <https://scholarship.law.stjohns.edu/tcl/vol2/iss3/7>.

${ }^{63}$ Leopold Pospisil, Anthropology of Law. Translator Derta Sri Widowati. Antropologi Hukum Sebuah Teori Komparatif. (Bandung: Nusa Media, 2016). 
"... The distribution of inheritance according to adat has many weaknesses. Daughters are not entitled to be heirs. In addition, most of the eldest sons who received the mandate as heirs were unable to carry out their obligations fairly. Heirlooms that should be used for common interests, caring for parents, younger siblings until adulthood, in practice are used for their own needs..." ${ }^{64}$

The same thing is commented by the traditional Sai Batin leader, Rusli, ${ }^{65}$ who assess the distribution of inheritance through transfer is no longer following the current situation. He shared his experiences

".... . In 1997 there was an inheritance dispute in which the inheritance fell into the hands of the eldest son. As usual, other family members, namely his younger siblings, did not receive anything as all the assets left by their parents fell to their eldest brother. The siblings, however, rose objection as they also had the necessities of life and a huge expense for their children. The most persistent was coming from the daughters who urge that the assets be divided using Islamic Law. Due to protests from the family members, a family meeting was held by presenting traditional figures and elders. During the family meeting, it was decided that the sons and daughters of the deceased would receive an inheritance in the form of one plot of land for each of them. Evidence of the agreement was written on a sheet of paper with a 6,000 stamp and signed by each of the heirs and traditional leaders and elders."

Contrary to the previous statement, Gurti Komarawati, a traditional leader from Lampung who is also the Queen of the Batu Bekhak clans states: "... the people have no other choice but to continue with the customs instilled by the previous ancestors. Sons and daughters who are not the eldest son should understand that they are not entitled to inheritance ..." But Gurti also admits that there has been a shift in law in society in the form of similar rights for daughters and sons to receive a share. It, however, depends on the wisdom of the oldest sons. Gurti gives an example that in her extended family all daughters have the same rights as sons do. ${ }^{66}$

The influence of social interaction, education, and information is the most significant factor in the cultural shifts. This is as pointed out by

${ }^{64}$ Syamsuddin, the customary people of the Sai Batin Lampung tribe in Pekon Gunung Kemala Bandakh, Interview on 15 July 2018.

${ }^{65}$ Batin Juragan Muhammad Rusli, Interview on 12 July 2018.

${ }^{66}$ PUN Gurti Komarawati, Lampung traditional figure who is also Queen Batu Bekhak, Interview on 18 July 2018'. 
a community leader who received a boarding school education, named Sadaruddin. According to Sadarudin, customs have many weaknesses, one of which is related to the distribution of inheritance. The way of sharing inheritance in Islam is much fairer than the traditional way. This is because all children are counted as heirs, which is different from customary law that only favors the oldest child.:67 In order to avoid internal family strife, some Sai Batin people choose to share their assets with their descendants while they are still alive through the means of hibah (grants) which are seen as an effective way, fair and equitable.

The description above indicates that there has been a degradation of inheritance law from customary inheritance to Islamic inheritance law, because apart from the external factors mentioned earlier, internally the influence of Islam on the Sai Batin tribe is indeed stronger when compared to the Pepadun tribe. ${ }^{68}$ Apart from all, it is interesting that even though there are conflicts, especially about inheritance, the case will never go to court, because for them inheritance disputes are disgraceful and dishonorable in the eyes of the indigenous people.

\section{Conclusion}

The Sai Batin tribe is still strong in maintaining its traditions. This is indicated by the fact that the majority of the people are still adhering to the jujur marriage system as well as the inheritance system based on male lineage. Unfortunately, however, there has been a gradual degradation in obeying the traditional law as some people think that traditional inheritance does not provide a sense of justice, so they turn to Islamic law as they consider it juster. Apart from disturbing the sense of injustice that demands a change in the law, the main factor contributing to the degradation of customary law among the Sai Batin indigenous people is the interaction between two different laws - Sai Batin customary law and Islamic law. It can be predicted that, in the future, society would

${ }^{67}$ Ahmad Sadaruddin, the indigenous people of the Sai Batin Lampung tribe in Pekon Sekincau, Interview on 13 July 2018'.

${ }^{68}$ Titik Pudjiastuti, Aksara Dan Naskah Kuno Lampung Dalam Pandangan Masyarakat Lampung Kini, p. 20. 
adjust accordingly with new laws to get a better legal system and in accordance with their sense of justice.

\section{Bibliography}

Achmad Sodiki, 'Penataan Kepemilikan Hak Atas Tanah Di Daerah Perkebunan Kabupaten Malang. (Studi Tentang Dinamika Hukum).' (Airlangga University Postgraduate Program, 1994)

Adil Niat Gulo, 'Degradasi Budaya Dalam Upacara Perkawinan Masyarakat Nias Di Denpasar | E-Jurnal Kajian Budaya (Online Journal of Cultural Studies)' <https://ojs.unud.ac.id/index.php/kajian/article/view/4826>

Ahmad Sadaruddin, the indigenous people of the Sai Batin Lampung tribe in Pekon Sekincau, Personal Interview, 2018

Alting, Husen, 'Penguasaan Tanah Masyarakat Hukum Adat (Suatu Kajian Terhadap Masyarakat Hukum Adat Ternate)', Jurnal Dinamika Hukum, 11.1 (2011), 87-98 <https://doi.org/10.20884/1.jdh.2011.11.1.75>

Angkupi, Prima, 'Formulasi Perkawinan Adat Lampung Dalam Bentuk Peraturan Daerah Dan Relevansinya Terhadap Hak Asasi Manusia', Asy-Syir'ah: Jurnal Ilmu Syariah Dan Hukum, 49.2 (2015), 315-37 <https://doi.org/10.14421/asy-syir'ah.2015.\%x>

Batin Juragan Muhammad Rusli, Interview,on 12 July 2018

David Knowles, O.S.B.; D. Litt.; F.B.A., 'Lex Injusta Non Est Lex', The Catholic Lawyer, 2.3 (2016) <https://scholarship.law.stjohns.edu/tcl/ vol2/iss3/7>

Dewi Wulansari, Hukum Adat Indonesia Suatu Pengantar, 3 (Bandung: Refika Aditama, 2014)

Edward Syah Pernong, '100 Tokoh Terkemuka Lampung', Lampung Post, 2008

Fachruddin, 'Memahami Etika Dalam Kitab Kuntara Rajaniti Dalam Rangka Mengenal Identitas Budaya Lampung', <http://ulun. lampunggech.com/2008/10/manuskrip-kitab-kuntara-raja-niti.html>

Febra, Atiansya, 'Sistem Perwarisan Masyarakat Adat Saibatin Dalam Keluarga Yang Tidak Mempunyai Anak Laki-Laki (Studi di Kota Bandar Lampung)', Kumpulan Jurnal Mahasiswa Fakultas Hukum, 
0.0 (2015) <http://hukum.studentjournal.ub.ac.id/index.php/hukum/ article/view/1364>

Hari Purwadi, 'Reformasi Hukum Nasional: Problem dan Prospeknya', in Memahami Hukum: Dari Konstruksi Sampai Implementasi (Jakarta: Rajawali Press, 2011)

Hilman Hadikusuma, Hukum Perkawinan Adat, (Bandung: Citra Aditya Bakti, 1990)

—_- Masyarakat Dan Adat Budaya Lampung (Bandung: Mandar Maju, 1989)

'Hukum Waris Dan Wasiat (Sebuah Perbandingan Antara Pemikiran Hazairin Dan Munawwir Sjadzali) | Jamil | Al-Ahwal: Jurnal Hukum Keluarga Islam' <http://ejournal.uin-suka.ac.id/syariah/Ahwal/article/ view/1171>

Ibn Qoyyim al-jauziyah, I'lamul Muwaqiin, III (Beirut: Dar al- Kutub al-Arabiyah, t.t)

Inner Skipper Muhammad Ruslit, Interview Personal

Irham, Muhammad Aqil, 'Lembaga Perwatin Dan Kepunyimbangan Dalam Masyarakat Adat Lampung: Analisis Antropologis', Analisis: Jurnal Studi Keislaman, 13.1 (2013), 155-72 <https://doi.org/10.24042/ajsk. v13i1.684>

Kayen, Teguh, 'Hukum Adat Di Hadapan Politik Hukum Nergara: Studi Sosiologis Hukum Masyarakat Adat Rejang', Jurnal Jurisprudence, 5.2 (2017), 75-79-79 <https://doi.org/10.23917/jurisprudence.v5i2.4223>

Komari, 'Laporan Akhir Kompendium Bidang Hukum Waris' (Jakarta: Agency for Development of National Law, the Ministry of Justice and Human Right, 2011)

Kretzmann, Norman, 'Lex Iniusta Non Est Lex: laws on Trial in Aquinas' Court of Conscience', The American Journal of Jurisprudence, 33.1 (1988), 99-122 <https://doi.org/10.1093/ajj/33.1.99>

Leopold Pospisil, Anthropology of Law. Translator Derta Sri Widowati. Antropologi Hukum Sebuah Teori Komparatif. (Bandung: Nusa Media, 2016)

M. Adnan Bahsan, Zulchilal Bahsan and Badri Bahsan, 'Pelestarian Nilai-Nilai Adat Dan UpacaraPerkawinan Adat Lampung Pesisir' 
(presented at the Paper presented at the Anniversary of the University of Lampung, Lampung, 1982)

Marwan, Pratin Bumi Agung, Personal Interview, 2018

'Masyarakat Adat Lampung Saibatin : Tradisi - Situs Budaya Indonesia' $<$ https://www.indonesiakaya.com/jelajah-indonesia/detail/masyarakatadat-lampung-saibatin>

Meli Septania Adelina Hasyim Hermi Yanzi, 'Implementasi Nilai Kearifan Lokal Dalam Proses Upacara Pernikahan Adat Lampung Saibatin', Journal of Democracy Culture (JKD), 5.5, 2017

Moore, Sally Falk, 'Law and Social Change: The Semi-Autonomous Social Field as an Appropriate Subject of Study', Law \& Society Review, 7.4 (1973), 719-46 <https://doi.org/10.2307/3052967>

Munawir Sjadzali, Ijtihad Kemanusiaan (Jakarta: Paramadina, 1997)

Najib Burhani, Kebinekaan Kita (Daily Compass, 2020)

Nurcholish Madjid, Islam Doktrin dan Peradaban (Jakarta: Yayasan Wakaf Paramadina, 1992)

'Perubahan Pola-Pola Perkawinan Pada Masyarakat Lampung Saibatin | Imron | Jurnal Antropologi: Isu-Isu Sosial Budaya' <http://jurnalantropologi. fisip.unand.ac.id/index.php/jantro/article/view/216>

Pokok-Pokok Sosiologi Hukum Pokok-Pokok Sosiologi Hukum (Jakarta: Rajawali Pers, 2011)

PUN Gurti Komarawati, Lampung traditional figure who is also Queen Batu Bekhak, Personal Interview, 2018

R. Soebekti, Pokok-Pokok Dari Hukum Perdata, (Jakarta: Intermassa, 1985)

Rahman et al, 'Kajian Hukum Tentang Mekanisme Pengakuan Masyarakat Adat' (Center for Research and Development Systems National Law and Development of the National Law Kemenkumham RI, 2015)

Ridwan, Ridwan, 'Hukum Dan Perubahan Sosial:(Perdebatan Dua Kutub Antara Hukum Sebagai Social Control dan Hukum Sebagai Social Enginnering)', Jurnal Jurisprudence, 6.1 (2017), 28-39-39 <https:// doi.org/10.23917/jurisprudence.v6i1.2993> 
Satria Effendi M Zein, 'Munawir Sjadzali dan Reaktualisasi Hukum Islam Di Indonesia', in Kontekstualisasi Ajaran Islam, 70 Years Prof. Dr. Munawir Sjadzali, MA (Jakarta: Paramadina, 1995)

Sholihin, Bunyana, 'Hukum Bangsa Indonesia Dalam Naskah Klasik Beraksara Lampung (Undang-Undang Kuntara Rajaniti Dan Jugulmuda)', ASAS, 11.01 (2019), 38-48 <https://doi.org/10.24042/ asas.v11i01.4641>

Siddik, aji Abdullah, Hukum Adat Rejang (Jakarta: PN Balai Pustaka, 1980)

Sigit Sapto Nugroho, Hukum Waris Adat Di Indonesia (Solo: Pustaka Iltizam, 2016)

Sudarsono, Hukum Perkawinan Nasional, (Jakarta: Rineka Cipta, 1981) Syajrul, Ninawati, 'Upaya dan Penyelamatan Naskah Kuno Lampung | Manuskripta', Journal, Manuscriptta, 1.2 (2011) <http://journal. perpusnas.go.id/index.php/manuskripta/article/view/14>

Syamsuddin, the customary people of the Sai Batin Lampung tribe in Pekon Gunung Kemala Bandakh, Personal Interview, 2018

Syarifudin Basyar, Determinasi Nilai-Nilai Tradisi Terhadap Religiusitas Masyarakat (Kajian Adat Ninjuk Dalam Budaya Lampung (Lampung: Research and Publishing Center, LPPM IAIN Raden Intan Lampung, 2014)

Titik Pudjiastuti, Aksara Dan Naskah Kuno Lampung Dalam Pandangan Masyarakat Lampung Kini, (Jakarta: Putra Sejati Raya, 1996)

Wardojo, Koesno, 'Pergeseran Pandangan Terhadap Nilai Sosial Budaya Dalam Masyarakat Sebagai Akibat Pengaruh Kebudayaan', Equilibrium : Jurnal Ilmiah Ekonomi Dan Pembelajarannya, 1.1 (2013) <https://doi.org/10.25273/equilibrium.v1i1.553>

Yakin, Ayang Utriza, 'Undhang-Undhang Bantěn', Indonesia and the Malay World, 44.130 (2016), 365-88 <https://doi.org/10.1080/13 639811.2016.1229859>

Yaswirman, Hukum Keluarga: Karakteristik Dan Prospek Doktrin Islam Dan Adat Dalam Masyarakat Matrilineal Minangkabau (Depok: Raja Grafindo Persada, 2017) 